\title{
Scholarly Publishing in Malaysia: Origins and Current Development
}

\author{
${ }^{1}$ Hamedi M. Adnan, ${ }^{2}$ Mohamad Saleeh Rahamad \\ ${ }^{1,2}$ Department of Media Studies University Malaya 50603 Kuala Lumpur Malaysia
}

\begin{abstract}
Scholarly books in Malaysia are mainly published by university presses and government's research institutions. It is carried out as a social responsibility to disseminate knowledge from the researches done, mainly by government servant in the university or research institutions. As such, the number of academic books published in a year is relatively small with limited print-of-run. However, compared with her neighbouring countries, Malaysia has a good structure of governance in scholarly books publishing with the formation of Malaysian Scholarly Books Council or MAPIM which unify all university presses into a single body. This article discusses the history and development of scholarly publishing in Malaysia with the focus to the role of MAPIM of the governing body.
\end{abstract}

Keywords: scholarly publishing; university press; scholarly publishing; books; Southeast Asian publishing

\section{Introduction}

Scholarly publishing in Malaysia develops quite slowly although this kind of publication has already existed in the middle of 1950s. In the 1960s there were three scholarly publishing entities in this country, which are University of Malaya Press (UM Press), Language and Literary Agency or Dewan Bahasa dan Pustaka (DBP) and Oxford University Press (OUP). The total number of book titles that were published at this early stage could not be identified since the available source did not separate the quantity of academic and nonacademic books. In 1966, data from the National Library showed that the total number of books which were published in this country were 563 titles. If estimated the number of scholarly books is only ten percent out of the total number of books, and therefore the total number of scholarly books every year in the 1960s was around 56 titles.

Only in the 1970s other university press, besides UM Press, was established. Science University of Malaysia (USM) established its publication in 1969, followed by National University of Malaysia (UKM) (1971), and Agriculture University (UPM) (1972). This was then followed by other universities such as University Technology Malaysia (UTM), Northern University of Malaysia (UUM), International Islamic University (IIU), and MARA Institute of Technology (ITM) in the 1980s. At this time too, academic publishers in this country started to adjust their own activities for the necessity of all the publishers. The Committee of Malaysian Academic Publishing or PEPET was established in 1985 as an effort to combine publishers of higher institutions and research bodies in a loose co-operation.

In 1996, the government through the Education Ministry began to give attention to the scholarly publishing situation in this country. As a result the Malaysian Academic Publishing Council or MAPIM was established. There was not much difference between the intention of MAPIM and PEPET, except that this time MAPIM obtained support from the government. The MAPIM Board meeting which makes plans of programs for the benefits of the members was held every year, and the members met to discuss issues together, especially on joint book marketing and editorial training.

Issues on scholarly publishing in Malaysia were discussed by Beda Lim (1973: 271-78), Lim Chee Hong (1985: 33-39) and Hamedi (1996). Beda Lim discussed academic publishing situation in the 1970s by focusing on University Malaya Press as the oldest academic publisher in this country. Chee Hong continued the discussion by focusing on scholarly publishing in the 1980s. Hamedi had discussed the role of DBP as the largest academic press, especially on its marketing and distribution. Generally, scholarly book publishing in Malaysia is very small compared to other types of books. Latest statistics by the National Library shown that in 2009 only 357 new scholarly titles were published in Malaysia out of 15,767 titles or only 2.2 percent from the whole production.

This article will discuss the history of scholarly publishing in Malaysia and development that involves two entities which are established to upgrade academic publishing, PEPET and MAPIM. The discussion will also focus on the latest development in scholarly publishing in Malaysia. 


\section{Early Development In Scholarly Publishing}

Scholarly publishing in the form of books is generally a new development which occurred after Malaysia achieved independence in 1957. Before that, scholarly publishing was done sporadically through journal publication such as Journal Malaya Branch of Royal Asiatic Society (JMBRAS). Sheppard (1985) discussed the history and development of this longest and surviving academic journal in Malaysia. However, the involvement of University Malaya - the oldest university in Malaysia — in scholarly publishing are even earlier, that was in 1954 when a Publication Committee which consists of a vice-chancellor as the Chairman, a librarian as the secretary, a Council representative, two Senate representatives, a representative from the Education Ministry and a representative from Oxford University Press (OUP) was established to monitor its publication activities. Although this committee establishment was not accompanied by the active scholarly publishing activities, this is the first time in Malaysian history that an effort was made to manage scholarly publishing. This committee involves Oxford University Press - a co-operation which was then continuous until 1969 in which within that period gave life to scholarly publishing development in University Malaya.

In 1959, the size of the University Malaya's Publishing Committee increased twice as much to enroll colleagues from Pantai Valley, Kuala Lumpur-a new established campus of the university. In the same year the secretary of the Committee were transferred from Singapore to Kuala Lumpur. Only in 1960 University Malaya Press was then registered as a private company that operated without financial support from the university. It only operated with a Board of Directors which consists of the University Malaya vice-chancellor as the chairman, the University Singapore vice-chancellor, two representatives each from the staffs of University Malaya and University of Singapore, and an accountant firm as the secretary. On the $22^{\text {nd }}$ of August 1960, both branches in Kuala Lumpur and Singapore established a limited company, named as the University of Malaya Press Ltd.

From 1954 to 1969, Oxford University Press helped University Malaya Press publication program directly. The Publishing Committee is to choose the manuscript to be published. The manuscript will be handed over to OUP which carried out editing, doing the layout, production, promotion and then marketing. Under this co-operation more than 50 academic book titles, particularly in the Malaysiana field was successfully published. Among the important titles are British Policy in the Malay Peninsula (Eunice Thio), Raffles of Singapore (Emily Hahn), The Conquest of Malacca (De Meneses), Piracy, Paramountcy and Protectorates (Alfred P. Rubin), The Origin of Malay Nationalism (William R. Roff), The Protected Malay States (Emily Sadka), The British in West Sumatra 1685-1825 (John Bastin), and Malaysia (Rupert Emerson).

In spite of this, one insufficiency which is obvious is the rarity of books that are written by local writers. Most book titles which are published were written by foreign writers who usually have published the work in London or New York. The work was published again with the UM Press imprint for market in the Malaysian territory. However, this is the effort which could promote the UM Press to become academic book publisher that is honored in the South-East Asian territory at that time. Only in the 1970s in which after the UM Press-OUP co-operation ended then only the local writer work gradually began to be published. Among those included are The Oil Palm Industry of Malaysia (Harcharan Singh Khera), Western Rubber Planting Enterprise in Southeast Asia (Voon Phin Keong), and From Malayan Union to Singapore Separation (Mohamad Nordin Sopiee).

The UM Press and OUP co-operation had to be ended on the $31^{\text {st }}$ of October, 1969, since the New Economic Policy wanted OUP to change its ownership structure by reducing foreign holding and giving more ownership to the local people. In order to reflect its image as a local ownership publisher, Fajar Bakti was established with OUP holding of only 30 percent. This ownership change also indicates foreign capital reduction in local publishing and the OUP name in Malaysia that is well-known in the whole world as a famous academic publisher had also eroded. The Fajar Bakti, although did publish scholarly books as well, was not able to maintain the OUP reputation when later, on a commercial basis, began to change direction to school textbook and reference book business which are more profitable.

The government's language and literary agency, Dewan Bahasa dan Pustaka (DBP) began to publish books in 1959, although its involvement in scholarly publishing began in the late 1960s and early 1970s. The focus of DBP in the beginning was to publish textbooks in Malay for school use (Hamedi 1996: 34). In 1965, only two titles of academic books were published (Hassan 1975: 88). This total number expanded later due to increased necessity for academic books, particularly in translation work. With the National University of Malaysia or UKM establishment in 1970, there was a lot more insistence for DBP to increase the number of titles in Malay language. By 1975, 38 higher learning textbooks were successfully published with 177 more being in various processes to be published (Hassan 1975: 90-1). By 1985, Hassan Ahmad reported that DBP successfully published 329 books for higher learning in Malay language (Hassan Ahmad 1985: 151). From the total number, 131 was original work, while the remainder was translation work, particularly from English language. 
The University Malaya and DBP success in scholarly publishing became a model for universities which appeared later. USM was established in 1969 and at an early stage carried out many translation projects with the co-operation from DBP. By deploying expertise from faculties at the university, USM Press was successful in forming its Publication Committee which was stable and always contributed to excellence in publishing (Lim Chee Hong 1973). UKM established its publication unit in 1970 by introducing a policy which determined that all scholarly publications in the form of books, journal and others which are produced in the University should be channeled through this publisher (Anon. 1995: 9). This policy helped the UKM scholarly publishing development a lot in which with better infrastructure and working scheme had appeared as one of the main academic publishers in the later years.

Agriculture University (later named Putra University) or UPM established its publication unit in 1972 that used USM model by placing it under the Library - a modus operandi which was also practiced in University Malaya at the early stage (Hamedi 2004: 1-8). This situation caused confusion, particularly to those who did not understand the processes in scholarly publishing. In addition, knowledge in academic publishing among publishers was not stable yet. Beda Lim - a librarian who was assigned to manage UM Press reported about scholarly publishing situation in this country in which according to him "the book publishing scene in Malaysia is rather confusing". He reported that publishing, printing, and book selling business was not only unstable but was also completely disorganized and confusing. He gave close attention that there was no specification in each of their area of task with an editor having to carry out various kinds of tasks, including marketing job (Beda Lim 1973: 273).

Other scholarly publishers were continuously established in the 1980s, while the available university publishers and DBP continued to consolidate their job and achievement in scholarly publishing, particularly in Malay language in which since 1983 was made the medium of instruction in all higher learning institutions. Other universities are such as University Technology (UTM), Northern University (UUM), International Islamic University (IIU), and MARA Institute of Technology (ITM) also entered scholarly publishing in the 1980s.

Scholarly publishing development before that had gained encouragement when the government established the Malaysian Book National Council (MBKM) in 1968. MKBM was established under the Education Ministry based on a suggestion from UNESCO which requested all developing countries to establish their own national book council in order to assist development in book publishing. However MBKM did not function properly until 1981 when the Education Ministry reactivated it. In 1982 the government gave a grant as much as RM100,000 (US\$250,000) to MBKM to enable it to carry out activities more effectively, particularly to develop interest in reading. One of the MBKM activities which are permanent until now is organizing the Kuala Lumpur Book Fair in which in 2014 reached 33 years.

\section{The Establishment of PEPET}

In 1985, The Publishing Committee for Malaysian Institutes of Higher Learning (PEPET) was established. Its main objective is to adjust the publishing activities of all universities, research institutions and DBP. At the early stage, it was found that scholarly publishing in Malaysia faced various problems-its staff members faced problems in language competence, lacking in knowledge on editorial processes, financial management and publishing projects, production, invention, and marketing. They also faced job specification problems where the staff members who manage editorial have to take care of production and layout as well.

In order to fulfill its function, PEPET carried out various training programs such as conference, seminar, and workshop either independently or with co-operation from other bodies. One of the organizations which established co-operation with PEPET is International Development Research Centre (IDRC), Canada in which in its three years assistance program had helped PEPET to prepare information and database towards inculcating professionalism in their own institution publishing management. One of the projects that carried out in this co-operation is exposing members with international scholarly publishing practice such as university publisher consortium establishment, co-operation in marketing and warehousing, exposure to technology utilization to overcome staff shortage and others. Under this PEPET and IDRC co-operation, seven activities could be carried out, which are:

- Having training, seminar and workshop. Among the workshops that were organized were financial and project management, book editing, production and layout, language course, scholarly book marketing seminar, book distribution workshop, and seminar in the editor's role in journal publishing. The activities were managed by experts or staff members from IDRC, NRC, University of Toronto Press, DBP, and a few most important staff among PEPET members itself.

- Carrying out research on writing and reading. The purpose of the research is to identify the demography, situation and potential of Malaysian graduates as a basis in the scholarly writing formation in Malaysia; to gather information on academic material purchasing (including subscription), scholarly publishing and the reading behaviour in order to identify opportunities that can be taken by academic publishers; and to increase and renew the available mailing list. 
- $\quad$ Building publishing database, by listing all publications by university academic staffs. This database is built by using the CD-ISIS program that is placed in Northern University - and the result is PEPET was successful in publishing PEPET Publications List 1989 in conjunction with The Association of Southeast Asian Institutions of Higher Learning (ASAIHL) Seminar that was carried out in UKM in 1989.

- Participating in book fairs either at local or international level. Since most books published by PEPET members are in Malay language, they could only participate in book fairs in Jakarta and Singapore-usually by filling free stalls reserved for MBKM by the organizer. They participated in local book fairs as well, particularly at the state level besides book exhibition at the location where they have the PEPET meeting, particularly at the institution of the member who becomes the host.

- Having training for scientific writing. PEPET feels that the necessity which is urgent to train writers in science and technology field to write in Malay language. They were also exposed to various aspects in publishing, including the command of the Malay language, copyright, writing techniques, index preparation, publication method, and others.

- Having educational visit to various publishing institutions, including publishers, research institutions, and bookstores in Indonesia, Canada, Britain, and the USA. The purpose is to gain exposure on publishing management.

However at this stage university publishers did not get direct assistance from the government. According to Mohd Ariffin, the government felt that DBP as a government statutory body ought to be given the opportunity and space to develop and therefore all publication efforts should be centered in DBP (Mohd Ariffin 1996: 1-17). This opinion was definitely disagreed by university publishers who felt that it was necessary for them to continue with their existence as a different entity to carry out publishing activities for their main university in their specific field. Except University Malaya which continued to operate independently like a private publishing company, all other universities received publication fixed allocation from each of their institutions that provides payment of wages and are taken care for its operational costs.

By 1989 when PEPET had the Regional Conference on Scholarly Publishing it was reported (Mohd Ariffin 1996) that this organization has 13 members who are active, which are seven university publishers, four research institutes (MARDI [agriculture], PORIM [palm oil], RRIM [rubber], and FRIM [forest]) and DBP. Research institutes were active as well in the publications, either in the form of books, journals or brochures concerning their own field. Private sectors in general avoid academic publishing due to problems of limited market. On average only 1,000 copies of books were printed and it is uncertain that the total number can be finished in five years. In fact, private publishers have more tendencies to get involved in school textbooks or school reference books publishing in which the market is more profitable.

According to the statistics in 1985, only 429 scholarly books were published with DBP contributing the largest amount with 252 titles. A big part of it was translation work for textbook use in higher institutions which began using Malay as the medium of instruction in 1983. Table 1 shows the number of titles published university presses and DBP in 1985.

Table 1: Number of scholarly books in Malaysia (1985)

\begin{tabular}{|l|l|}
\hline Institutions & Number of titles \\
\hline University Malaya & 50 \\
National University (UKM) & 51 \\
Agriculture University (UPM) & 16 \\
Science University (USM) & 50 \\
Technology University (UTM) & 5 \\
MARA Institute of Technology (ITM) & 5 \\
Dewan Bahasa dan Pustaka & 252 \\
\hline Total & $\mathbf{4 2 9}$ \\
\hline
\end{tabular}

Source: Lim Chee Hong (1985:39)

In 1990, Hasrom Haron (1994: 33) estimated that the total number of scholarly publications was increased to 440 titles. In that year, DBP continued to be dominant with scholarly publication quantity being more than 200 titles, including translation work. The private publisher involvement was very little although Fajar Bakti which is owned by Oxford University Press was still publishing scholarly books, specifically in the form of higher learning textbooks.

After the co-operation program with the IDRC ended, PEPET activities had decreased. Provision nonavailability for activities and its early motivators being busy with duties caused PEPET to become more deteriorated. Hasrom Harun who led PEPET began to change focus to Malaysian Book Publishers Association (MABOPA) which he led in the first half of 1990s. Another activist such as Abdul Manaf Saad from UM Press had resigned to work in private press that did not publish scholarly books. A few early activists either had 
changed duties due to promotion or had ended their services - and this situation caused PEPET to be unable to run smoothly.

\section{The Establishment of MAPIM}

After a few years, academic publishing activities deteriorated without centered adjustment, finally an agreement to replace PEPET was established. This time its establishment initiative is to gain support from the government through the Education Ministry. The Council for Malaysian Academic Publishing or MAPIM was established on the $11^{\text {th }}$ of July 1996 as an outcome of the DBP-IPT Technical Meeting which was held in the DBP Sarawak Branch in Kuching. At the early stage, DBP, six university publishers (UM, UKM, UPM, USM, UTM, and UUM), and MARDI participated in MAPIM. Later on the $22^{\text {nd }}$ of May 1997, the Meeting of Steering Committee of MAPIM had determined organizational structure of Council membership. As such, the MAPIM establishment was official as an academic publishers association in which its general objective is to strengthen academic and scientific book publishing.

In the year 2000, its organization was restructured with the existence of MAPIM Council Regulations. With this restructuring, the head of committee who worked before this was replaced with the Council of MAPIM which was placed at the Higher Education Department, Ministry of Education. The MAPIM Council was chaired by the Higher Learning Department Director, Prof. Dr Hassan Said. According to the MAPIM Regulations, its general objective is to increase and develop scholarly publishing in Malaysia, specifically among public university publishers, research centers and DBP. Others are to have co-operation and scholarly publishing activity adjustment from time to time among Malaysian academic publishers, research centers, DBP, and other publishers involved; build scholarly publishing infrastructure specifically in terms of financial policy, structure and organization, editorial, production, marketing and training; and create information network which are useful for the purpose of studying publishing development closely in order to avoid time, energy, expertise and financial wastage.

Meanwhile, its specific objective is to have the Council meeting from time to time to discuss the development of scholarly publishing; have co-operation in book publishing activities, monograph and journal; have co-operation in marketing, promotion, exhibition, book publishing as well as catalog distribution activities; plan, arrange and organize workshops, seminars, and courses in the scholarly publishing field.

The MAPIM membership is divided into ordinary member and associate member. The ordinary membership is open to universities under the authority of Education Ministry that carries out academic publishing activities. The associate member category is open to research institutes and public institutions that are active in scholarly publishing. Its membership increased when University College that was just established participated in MAPIM besides receiving memberships from other research institutes. By 2010, its membership has increased to 27 , consist of 21 public universities, five research institutes and one institute which concentrate on translation.

With the existence of MAPIM publishing co-operation, scholarly publishing infrastructure development, specifically in terms of policy adjustment, organizational structure, editorial processes, production, marketing and training among members can be adjusted. This indirectly can avoid wastage of energy as well as human resources. The MAPIM Council meeting which was held twice a year became a platform for the organization in planning the policy and direction in scholarly publishing for the country. Each member would report his publishing activities and this is one form of monitoring which was done by the government to ensure that the scholarly publishing which was carried out by each member follows the determined policy.

MAPIM through the office of Higher Education Director, Ministry of Education allocated fund to carry out its activities. The contribution enables MAPIM members to have workshops, book launching, and participate in local book festivals. Since 2004, MAPIM members were given free stalls in the institutes of higher learning Research Exhibition. The MAPIM Marketing workshop was successfully organized in August 2004 and August 2010 with subsidy from the government. Besides, MAPIM members also had the opportunity to participate in various book exhibitions in or outside the country. In 2005, MAPIM for the first time opened a stall at the Indonesian International Book Fair in Jakarta and in 2006 they participated in the Brunei Book Fair through free stalls provided by MBKM.

Besides new programs being carried out collectively involving members, each member organized their publishing activities as well. In 2002, 57 publishing activities had been carried out by MAPIM members, who usually gained privileges such as price reduction for participation. Among the activities included were writing and publishing workshops, translation and editing courses, book launching, and training in layout (Wan Sakinah 2004: 27-34).

In terms of achievement in publishing, throughout the six years since 2000, at least as many as 1,067 academic book titles had been published by MAPIM members. The total number does not include the ones published by DBP in which since 2000 began to lessen its involvement in scholarly publication that was less 
profitable. In three years since 2000, on average 145 book titles had been published by MAPIM members. This total number increased to more than 200 titles beginning from 2003. Although there was an increase in local scholarly book production, the total number is much smaller than the academic population in this country. Table 2 shows the production of scholarly books by of MAPIM members from 2006 to 2010. The total of 1,461 new titles was published by 12 active members with the average of 292 titles each year. The most productive of scholarly press is MARA University of technology with 253 new titles in four years. In general, the numbers of academic staff who produce scholarly books are still very small and this situation ought to be seen as something worrying. As such, each presses by individually or collectively by MAPIM has to do something to increase the number of new title, at least to reflect the total number of academic staffs in Malaysia which is now in 2011 has increased to more than 25,000.

Table 2: Scholarly books production by members of MAPIM (2006-2010)

\begin{tabular}{|l|c|c|c|c|c|c|}
\hline UNIVERSITY/ & $\mathbf{2 0 0 6}$ & $\mathbf{2 0 0 7}$ & $\mathbf{2 0 0 8}$ & $\mathbf{2 0 0 9}$ & $\mathbf{2 0 1 0}$ & TOTAL \\
YEAR & & & & & & \\
\hline University Malaya (UM) & 79 & 06 & 12 & 20 & 21 & 138 \\
\hline National University (UKM) & 41 & 25 & 31 & 28 & 35 & 160 \\
\hline University Technology (UTM) & 17 & 30 & 26 & 12 & 28 & 113 \\
\hline University Putra (UPM) & 17 & 15 & 39 & 28 & 27 & 126 \\
\hline University of Science (USM) & 33 & 26 & 34 & 29 & 26 & 148 \\
\hline Northern University (UUM) & 19 & 17 & 19 & 22 & 14 & 91 \\
\hline International Islamic University (IIU) & 32 & 04 & 30 & 79 & 05 & 150 \\
\hline Sarawak University (UNIMAS) & 08 & 02 & 01 & 01 & 13 & 25 \\
\hline Sultan Idris Education University (UPSI) & 18 & 18 & 13 & 11 & 06 & 66 \\
\hline MARA University of Technology (UITM) & na & 60 & 42 & 79 & 72 & 253 \\
\hline Science Islamic University (USIM) & 15 & 18 & 20 & 12 & 20 & 85 \\
\hline Technical University of Melaka (UTEM) & 12 & 05 & 13 & 36 & 40 & 106 \\
\hline TOTAL & 291 & 226 & 280 & 357 & 307 & 1,461 \\
\hline
\end{tabular}

Source: Reports to MAPIM and Catalogues of MAPIM members (2006-2010)

\section{Conclusion}

Although a lot of problems has to be faced by scholarly press in Malaysia, credit should be given to them for their organized structures and governance. Compared to its neighboring countries, where scholarly publishing is a matter of interest by respective scholarly publishers and no direct involvement from the state, in Malaysia, they enjoy the full support from the government through the Director General office of Higher Learning Department. Special allocation is given for MAPIM members to do various activities, such as participation in book fairs, and also the launching of annual MAPIM Award. Each year more than RM100,000 (US\$35,000) were allocated for MAPIM to organize this award, including a gala dinner in a five-star hotel where various categories will be presented, usually by the Minister of Higher Learning education. However, in terms of output, a lot of things need to be done, especially in producing good quality of new titles, titles that represents Malaysian academic standing in the international platform.

\section{References}

[1]. Anon. 1995. Suku Abad Penerbit UKM (A Quarter Century of UKM Press). Bangi: Penerbit UKM.

[2]. Beda Lim. 1973. Scholarly publishing in Malaysia. Scholarly Publishing 4, 3 (April): 271-78.

[3]. Hamedi Mohd Adnan. 2004. Scholarly publishing in Malaysia: Problems and prospects of the University Malaya Press. In Round Table Meeting of ASEAN Scholarly Publishers, University of Philippines, Manila.

[4]. Hamedi Mohd Adnan. 1996. Publishing and Book Marketing in Malaysia. Kuala Lumpur: Universiti Malaya Press.

[5]. Hasrom Harun. 1994. Towards the development of book industry in Malaysia. In Hasrom Harun, ed., MABOPA: Book Publishing and the Role of Publishers. Petaling Jaya: Malaysian Book Publishers Association.

[6]. Hassan Ahmad. 1975. The publishing programme of the Dewan Bahasa dan Pustaka. In Ungku Aziz, ed., Scholarly Publishing in South-East Asia. Kuala Lumpur: Association of Southeast Asian Institutions of Higher Learning.

[7]. Hassan Ahmad. 1985. The role of Dewan Bahasa dan Pustaka in the advancement of indigenous academic publishing in Malaysia. In S. Gopinathan, ed., Academic Publishing in ASEAN. Singapore: Festival of Books Singapore.

[8]. Lim Chee Hong. 1985. Academic publishing in Malaysia with particular reference to Universiti Sains Malaysia Press. In S. Gopinathan, ed., Academic Publishing in ASEAN. Singapore: Festival of Books Singapore.

[9]. M. Sheppard. 1985. The Journal of the Malaysian Branch of the Royal Asiatic Society: Its history, publications and distribution in ancient and modern times. In S. Gopinathan, ed., Academic Publishing in ASEAN. Singapore: Festival of Books Singapore.

[10]. Mohd Ariffin Mohd Siri.1996. Scholarly publishing in Malaysia with special reference to the IDRC-PEPET project. In Regional Conference on Scholarly Publishing. Kuala Lumpur: Dewan Bahasa dan Pustaka.

[11]. Wan Sakinah Wan Ibrahim, 2004. Penerbit IPTA dan penerbitan dalam bahasa Melayu: Pengalaman anggota MAPIM. In Mohd Anwar Ridhwan, ed., Penerbitan Buku Dalam Bahasa Melayu: Cabaran dan Pengalaman. Kuala Lumpur: Dewan Bahasa dan Pustaka. 